\title{
Pengaruh Service Excellent dan Nilai Nasabah terhadap Kepuasan Nasabah Kredit PT. Bank Mandiri Cabang Kesiman di Denpasar
}

\author{
I Kadek Sepiawan ${ }^{1}$ \\ Gusti Ayu Wimba ${ }^{2}$ \\ ${ }^{1,2}$ Fakultas Ekonomi Bisnis dan Pariwisata Universitas Hindu Indonesia \\ Email : kadeksepiawan@gmail.com
}

\begin{tabular}{|l|l|l|}
\hline Diterima: 20 desember 2020 & Direvisi: 22 desember 2020 & Disetujui: 24 desenber 2020 \\
\hline
\end{tabular}

\begin{abstract}
Customer satisfaction is a feeling of satisfaction or disappointment for someone resulting from a comparison of product performance or results with expectations. The formulation of the problem in this study is, how is the effect of service excellence and customer value on customer satisfaction at PT. Bank Mandiri branch of Kesiman in Denpasar. The purpose of this study was to determine the effect of Service Excellent and Customer Value on Credit Customer Satisfaction at PT. Bank Mandiri Kesiman Branch in Denpasar. This research was conducted at PT. Bank Mandiri Kesiman Branch in Denpasar. The number of samples taken was 93 customers, with the NonProbability sampling method, especially purposive sampling. The analysis technique used is multiple linear regression, $t$ test (partial) and $F$ test (simultaneous). Based on the analysis, it is found that Service Excelent and Customer Value simultaneously influence customer satisfaction, and partially service excellence and customer value have a positive and significant effect on customer satisfaction.
\end{abstract}

Keywords: Excellent Service, Customer Value, and Customer Satisfaction

\begin{abstract}
ABSTRAK
Kepuasan Nasabah merupakan perasaan puas atau kecewa seseorang yang dihasilkan dari perbandingan performa produk atau hasil dengan ekspektasi. Rumusan masalah pada penelitian ini adalah, bagaimana pengaruh service excellent dan nilai nasabah terhadap kepuasan nasabah pada PT. Bank mandiri cabang kesiman di denpasar. Tujuan penelitian ini adalah untuk mengetahui Pengaruh Service Excellent Dan Nilai Nasabah Terhadap Kepuasan Nasabah Kredit Pada PT. Bank Mandiri Cabang Kesiman Di Denpasar. Penelitian ini di lakukan pada PT. Bank Mandiri Cabang Kesiman Di Denpasar. Jumlah sampel yang diambil sebanyak 93 orang nasabah, dengan metode NonProbability sampling, khususnya Purposive Sampling. Teknik analisis yang digunakan adalah regresi linier berganda, uji $\mathrm{t}$ (parsial) dan uji F (simultan). Berdasarkan hasil analisis ditemukan bahwa Service Excelent dan Nilai Nasabah berpengaruh secara simultan terhadap kepuasan nasabah, serta secara parsial service excellent dan nilai nasabah berpengaruh positif dan signifikan terhadap kepuasan nasabah.
\end{abstract}

Kata Kunci : Service Excellent, Nilai Nasabah, dan Kepuasan Nasabah 


\section{PENDAHULUAN}

Meningkatnya pertumbuhan permintaan domestik kemudian berdampak pada tingginya pertumbuhan impor, di tengah kinerja ekspor yang relatif terbatas . salah satu sektor ekonomi yang mendukung pertumbuhan ekonomi Indonesia ialah sektor perbankan. Dimana Bank adalah lembaga intermediasi keuangan yang bertugas menghimpun dan menyalurkan dana di masyarakat untuk meningkatkan taraf hidup rakyat. Setelah menghimpun dana dari masyarakat. Bank menyalurkan dana kepada pihak-pihak yang membutuhkan melaui system kredit atau pinjaman. Kredit ini memiliki beberapa jenis kredit seperti kredit usaha mikro (KUM), kredit usaha rakyat (KUR) dan kredit serba guna mikro (KSM).

Menurut Kotler Dan Keller (2012:150) Kepuasan adalah perasaan puas atau kecewa seseorang yang dihasilkan dari perbandingan performa produk atau hasil dengan ekspektasi. Jika performanya kurang dari ekspektasi maka pelanggan akan kecewa dan jika sesuai dengan ekspektasi konsumen akan merasa puas. Kepuasan pelanggan dalam lingkup teori dan praktek pemasaran telah menjadi konsep sentral dengan tujuan esensial bagi aktivitas bisnis (Tjiptono, 2014).

Menurut Kotler dalam Bakri (2015:13) pelayanan atau service adalah setiap kegiatan atau manfaat yang dapat diberikan suatu pihak kepada pihak lainnya yang pada dasarnya tidak terwujud dan tidak pula berakibat pemilikan sesuatu dan produksinya dapat atau tidak dapat dikaitkan dengan suatu produk fisik. Menurut Kotler dalam Bakri (2015:13) mengemukakan pelayanan atau service adalah setiap kegiatan atau manfaat yang dapat diberikan suatu pihak kepada pihak lainnya yang pada dasarnya tidak terwujud dan tidak pula berakibat pemilikan sesuatu dan produksinya dapat atau tidak dapat dikaitkan dengan suatu produk fisik.

Slywotzky dalam Astono (2017) menyatakan bahwa nilai nasabah (customer value) adalah perpektif nasabah dalam mempertimbangkan apa yang mereka inginkan dan yakini dari pembelian dan penggunaan suatu produk, Zeithaml dalam Astono (2017) yang menyatakan bahwa nilai nasabah (customer value) adalah penilaian keseluruhan nasabah terhadap utilitas sebuah produk atau layanan berdasarkan persepsinya terhadap apa yang diterima dan uang diberikan. Menurut khaeirunisa (2013) menyatakan bahwa service excellence berpengaruh signifikan terhadap kepuasan nasabah. Pernyataan ini didukung oleh Asih (2013) yang menyatakan bahwa service excellence berpengaruh signifikan terhadap kepuasan nasabah.

Menurut Hashim dan Latifah (2010) dan Seiler et. al (2013) menyatakan bahwa nilai nasabah mempunyai pengaruh yang positif dan signifikan terhadap kepuasan pelanggan. Nilai koefisien sebesar o,231 menunjukan persepsi konsumen terhadap nilai (value) yang diberikan perusahaan 
dapat meningkatkan kepuasan pelanggan.Pernyataan ini didukung oleh penelitian yang dilakukan Seminari (2017) yang menyatakan bahwa nilai nasabah berpengaruh signifikan terhadap kepuasan nasabah.

Salah satu usaha perbankan di Indonesia adalah Bank Mandiri dimana Bank Mandiri didirikan pada 2 Oktober 1998, sebagai bagian dari program restrukturisasi perbankan yang dilaksanakan oleh pemerintah Indonesia. Pada bulan Juli 1999, empat bank pemerintah yaitu Bank Bumi Daya, Bank Dagang Negara, Bank Ekspor Impor Indonesia dan Bank Pembangunan Indonesia dilebur menjadi Bank Mandiri, dimana masing-masing bank tersebut memiliki peran yang tak terpisahkan dalam pembangunan perekonomian Indonesia. Sampai dengan hari ini, Bank Mandiri meneruskan tradisi selama lebih dari 140 tahun memberikan kontribusi dalam dunia perbankan dan perekonomian Indonesia.

Sebagai perusahaan penyedia jasa, PT. Bank Mandiri Cabang Kesiman harus memberikan service excellentdan nilai nasabah sesuai dengan harapan nasabah agar tercapainya kepuasan nasabah kredit, karena kelangsungan hidup perusahaan ditentukan oleh jumlah nasabah kredit, apabila jumlah kredit sedikit, maka pendapatan perusahaan akan menurun. Tujuan yang ingin dicapai dalam penelitian ini adalah (1) untuk mengetahui pengaruh Service Excellent terhadap kepuasan nasabah kredit pada PT. Bank Mandiri Cabang Kesiman Di Denpasar, (2) untuk mengetahui pengaruh nilai nasabah terhadap kepuasan nasabah kredit pada PT. Bank Mandiri Cabang Kesiman Di Denpasar, dan (3) untuk mengetahui pengaruh Service Excellent dan nilai nasabah terhadap kepuasan nasabah kredit pada PT. Bank Mandiri Cabang Kesiman Di Denpasar.

\section{TELAAH LITERATUR DAN HIPOTESIS}

\section{Kepuasan Nasabah}

Kepuasan adalah perasaan senang atau kecewa aeaeorang yang muncul setelah membandingkan antara persepsi atau kesannya terhadap kinerja atau hasil suatu produk dan harapan-harapannya (Ammuji,2012). Menurut Kotler Dan Keller (2012:150) Kepeuasan adalah perasaan puas atau kecewa seseorang yang dihasilkan dariperbandingan performa produk atau hasil dengan ekspektasi. Jika performanya kurang dari ekspektasi maka pelanggan akan kecewa dan jika sesuai dengan ekspektasi konsumen akan merasa puas. Kepuasan pelanggan dalam lingkup teori dan praktek pemasaran telah menjadi konsep sentral dengan tujuan esensial bagi aktivitas bisnis (Tjiptono, 2014). 


\section{Service Excellent}

Menurut Kotler dalam Bakri (2015:13) pelayanan atau service adalah setiap kegiatan atau manfaat yang dapat diberikan suatu pihak kepada pihak lainnya yang pada dasarnya tidak terwujud dan tidak pula berakibat pemilikan sesuatu dan produksinya dapat atau tidak dapat dikaitkan dengan suatu produk fisik. Menurut Kotler dalam Bakri (2015:13) mengemukakan pelayanan atau service adalah setiap kegiatan atau manfaat yang dapat diberikan suatu pihak kepada pihak lainnya yang pada dasarnya tidak terwujud dan tidak pula berakibat pemilikan sesuatu dan produksinya dapat atau tidak dapat dikaitkan dengan suatu produk fisik. Menurut Tjiptono dalan Sunyoto (2014:240) kualitas pelayanan adalah suatu penyajian produk atau jasa sesuai dengan ukuran yang berlaku ditempat produk tersebut diadakan dan penyampaiannya setidaknya sama dengan yang diinginkan dan diharapkan konsumen.

\section{Nilai Nasabah}

Slywotzky dalam Astono (2017) menyatakan bahwa nilai nasabah (customer value) adalah perpektif nasabah dalam mempertimbangkan apa yang mereka inginkan dan yakini dari pembelian dan penggunaan suatu produk, Zeithaml dalam Astono (2017) yang menyatakan bahwa nilai nasabah (customer value) adalah penilaian keseluruhan nasabah terhadap utilitas sebuah produk atau layanan berdasarkan persepsinya terhadap apa yang diterima dan uang diberikan. Berdasarkan pendapat para ahli, nilai nasabah adalah persepsi dari sebuah utilitas produk dalam pempertimbangkan apa yang mereka inginkan.

\section{Hipotesis}

Berdasarkan uraian latar belakang, rumusan masalah, teori-teori pendukung kerangka pemikiran, maka hipotesis yang dapat dirumuskan dalam penelitian ini ialah sebagai berikut :

H1: Diduga Service Excellent berpengaruh positif dan signifikan terhadap kepuasan pelanggan pada PT Mandiri Cabang Kesiman Di Denpasar.

H2: Diduga nilai nasabah berpengaruh positif dan signifikanterhadap kepuasan pelanggan pada PT Mandiri Cabang Kesiman Di Denpasar.

H3: Diduga Service excellent dan nilai nasabah berpengaruh positif dan signifikan terhadap kepuasan nasabah Pada PT Bank Mandiri Cabang Kesiman Di Denpasar. 


\section{METODE PENELITIAN}

\section{Desain Penelitian}

Desain penelitian yang digunakan dalam penelitian ini adalah desain asosiatif yaitu suatu penelitian yang meniliti pengaruh suatu variabel terhadap variabel lainnya atau mengetahui hubungan antar variabel Sugiyono, 2013. Penelitian kuantitatif merupakan penelitian yang yang menggunakan data berupa angka serta dianalisis menggunakan alat statistik Indriantoro, 2013:12.

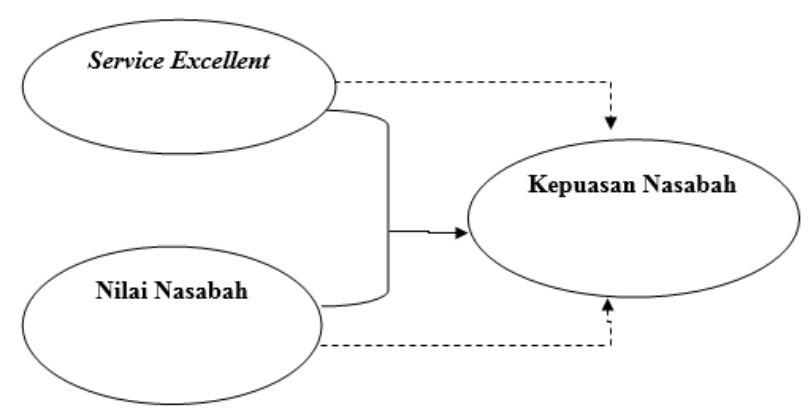

\section{Gambar 1. Kerangka Berpikir}

\section{Populasi dan Sampel}

Dalam penelitian ini yang menjadi populasi adalah seluruh nasabah kredit pada PT. Bank Mandiri Cabang Kesiman Di Denpasar periode tahun 2015 sampai dengan tahun 2018 sebanyak 1,236 nasabah, dengan menggunakan Rumus Slovin maka diperoleh sampel sebanyak 93 orang dan metode pengambilan sampling yang digunakan di dalam penelitian ini adalah purposive sampling.

\section{Metode Pengumpulan Data}

Metode yang digunakan dalam pengumpulan data untuk penelitian ini adalah observasi, wawancara, dokumentasi, kepustakaan, dan kuisioner. Skala yang dipergunakan dalam penelitian ini adalah skala likert (Sugiyono,2010) di dalam skala likert, kemungkinan jawabannya tidak hanya sekedar setuju atau tidak setuju. Melainkan dibuat dengan lebih banyak jawaban. Jawaban diberi nilai/skor yang akan merefleksikan konsisten jawaban responden yaitu Sangat Setuju (SS) diberi nilai 5, Setuju (S) diberi nilai 4, Kurang Setuju (KS) diberi nilai 3, Tidak Setuju (TS) diberi nilai 2, Sangat Tidak Setuju (STS) diberi nilai 1. 


\section{Analisis Data}

1. Uji instrumen penelitian, dilakukan dnegan uji validitas untuk mengetahui kemampuan suatu daftar pertanyaan untuk mengukur apa yang seharusnya diukur dan uji reliabilitas bertujuan untuk mencari tahu sampai sejauh mana konsistensi alat ukur yang digunakan.

2. Uji asumsi klasik, yang terdiri atas uji normalitas, uji multikolinearitas, dan uji heteroskedastisitas.

3. Analisis regresi linear berganda, digunakan untuk mengetahui ada tidaknya pengaruh secara serempak variabel bebas (service excellent/X1 dan nilai nasabah/X2) terhadap variabel terikat (kepuasan/Y).

\section{HASIL DAN PEMBAHASAN}

\section{Uji Instrumen Penelitian}

Dari Tabel 1 dapat diketahui bahwa semua item pernyataan dari masing-masing variabel Service Excelent, Nilai Nasabah, Kepuasan nasabah adalah valid. Dengan demikian, maka semua item pernyataan dari masing-masing variabel Service Excelent, Nilai Nasabah, Kepuasan nasabah adalah valid, sehingga semuanya diikutsertakan pada analisis lanjut. Selanjutnya berdasarkan nilai Cronbach's Alpha diperoleh nilai di atas 0,60 sehingga instrumen penelitian telah memenuhi syarat reliabilitas.

\section{Karakteristik Responden}

Responden dalam penelitian ini adalah sebanyak 92 orang nasabah yang dapat dijelaskan berdasarkan lima kategori atau karakteristik yaitu jenis kelamin, usia, pendidikan, pekerjaan, dan pendapatan.

1. Berdasarkan jenis kelamin, responden laki-laki dan perempuan yang menjawab kuesioner berjumlah 45 orang laki-laki (49\%) dan 47 orang (51\%). Hal tersebut menunjukkan bahwa rata-rata nasabah yang mengajukan kredit antara laki-laki dan perempuan hampir sama di Bank Mandiri Cabang Kesiman

2. Berdasarkan usia, dapat diketahui bahwa umur responden terbanyak yaitu umur $21-30$ tahun sebanyak 29 orang (32\%), usia 31 - 40 sebanyak 40 orang (43\%), sedangkan umur 41 - 50 tahun sebanyak 23 orang $(25 \%)$. Berdasarkan data di atas menunjukkan bahwa sebagian besar pengajuan kredit di Bank Mandiri cabang Kesiman didominasi oleh nasabah berumur kisaran 31-40 Tahun sebanyak $43 \%$. 
3. Berdasarkan tingkat pendidikan, dapat diketahui bahwa responden terbanyak dengan tingkat pendidikan Sarjanaberjumlah 46 orang (50\%), selanjutnya responden dengan tingkat pendidikan Diploma berjumlah 28 orang (31\%), tingkat pendidikan SMA berjumlah 18 orang (19\%). Berdasarkan tabel di atas terdapat berbagai macam tingkat pendidikan nasabah mulai dari sekolah menengah hingga sarjana, tetapi tingkat pendidikan yang paling dominan nasabah dengan tingkat pendidikan sarjana sebanyak 50\% atau 46 nasabah.

4. Berdasarkan pekerjaan dapat diketahui bahwa responden terbanyak dengan tingkat pekerjaanWiraswastaberjumlah 30 orang (33\%), selanjutnya responden dengan tingkat PekerjaanPegawai Negeri Sipil (PNS)berjumlah 25 orang (27\%), tingkat pekerjaanPegawai Swasta berjumlah 20 orang (22\%), tingkat pekerjaan Polri/ABRI Sebanyak 10 Orang (11\%), dan tingkat pekerjaan paling rendah adalah Pelajar/Mahasiswa sebanyak 7 Orang $(7 \%)$.

5. Berdasarkan pendapatan, dapat diketahui bahwa responden terbanyak dengan tingkat PendapatanRp. 6.000 .000 - Rp. 10.000.000berjumlah 38 orang (41\%), selanjutnya responden dengan tingkat PendapatanRp. 3.000.000 - Rp. 5.000.000berjumlah 25 orang (27\%), tingkat Pendapatan>Rp. 10.000.000berjumlah 19 orang (21), dan tingkat pendapatan <Rp. 3.000 .000 sebanyak 10 Orang (11\%).

6. Berdasarkan jenis kelamin, responden laki-laki dan perempuan yang menjawab kuesioner berjumlah 45 orang laki-laki (49\%) dan 47 orang (51\%). Hal tersebut menunjukkan bahwa rata-rata nasabah yang mengajukan kredit antara laki-laki dan perempuan hampir sama di Bank Mandiri Cabang Kesiman

7. Berdasarkan usia, dapat diketahui bahwa umur responden terbanyak yaitu umur $21-30$ tahun sebanyak 29 orang (32\%), usia 31 - 40 sebanyak 40 orang (43\%), sedangkan umur 41 - 50 tahun sebanyak 23 orang (25\%). Berdasarkan data di atas menunjukkan bahwa sebagian besar pengajuan kredit di Bank Mandiri cabang Kesiman didominasi oleh nasabah berumur kisaran 31-40 Tahun sebanyak $43 \%$.

8. Berdasarkan tingkat pendidikan, dapat diketahui bahwa responden terbanyak dengan tingkat pendidikan Sarjanaberjumlah 46 orang (50\%), selanjutnya responden dengan tingkat pendidikan Diploma berjumlah 28 orang (31\%), tingkat pendidikan SMA berjumlah 18 orang $(19 \%)$. Berdasarkan tabel di atas terdapat berbagai macam tingkat pendidikan nasabah mulai dari sekolah menengah hingga sarjana, tetapi tingkat pendidikan yang paling dominan nasabah dengan tingkat pendidikan sarjana sebanyak 50\% atau 46 nasabah. 
9. Berdasarkan pekerjaan dapat diketahui bahwa responden terbanyak dengan tingkat pekerjaanWiraswastaberjumlah 30 orang (33\%), selanjutnya responden dengan tingkat PekerjaanPegawai Negeri Sipil (PNS)berjumlah 25 orang (27\%), tingkat pekerjaanPegawai Swasta berjumlah 20 orang (22\%), tingkat pekerjaan Polri/ABRI Sebanyak 10 Orang (11\%), dan tingkat pekerjaan paling rendah adalah Pelajar/Mahasiswa sebanyak 7 Orang $(7 \%)$.

10. Berdasarkan pendapatan, dapat diketahui bahwa responden terbanyak dengan tingkat PendapatanRp. 6.000.000 - Rp. 10.000.000berjumlah 38 orang (41\%), selanjutnya responden dengan tingkat PendapatanRp. 3.000.000 - Rp. 5.000.000berjumlah 25 orang (27\%), tingkat Pendapatan>Rp. 10.000.000berjumlah 19 orang (21), dan tingkat pendapatan <Rp. 3.000.000 sebanyak 10 Orang (11\%).

Tabel 1 Hasil Uji Validitas dan Reliabilitas

\begin{tabular}{lllll}
\hline Instrumen & Validitas & & Reliabilitas & \\
\cline { 2 - 5 } Penelitian & Koefisien Korelasi & Keterangan & Cronbach Alpha & Keterangan \\
X1.1 & 0.850 & Valid & .944 & Reliabel \\
X1.2 & 0.785 & Valid & .947 & Reliabel \\
X1.3 & 0.816 & Valid & .945 & Reliabel \\
X1.4 & 0.833 & Valid & .945 & Reliabel \\
X1.5 & 0.815 & Valid & .945 & Reliabel \\
X1.6 & 0.770 & Valid & .947 & Reliabel \\
X1.7 & 0.787 & Valid & .946 & Reliabel \\
X1.8 & 0.741 & Valid & .948 & Reliabel \\
X1.9 & 0.769 & Valid & .947 & Reliabel \\
X2.3 & 0.812 & Valid & .964 & Reliabel \\
X2.4 & 0.844 & Valid & .963 & Reliabel \\
X2.5 & 0.769 & Valid & .965 & Reliabel \\
X2.6 & 0.732 & Valid & .967 & Reliabel \\
X2.7 & 0.871 & Valid & .963 & Reliabel \\
X2.8 & 0.880 & Valid & .963 & Reliabel \\
X2.9 & 0.821 & Valid & .964 & Reliabel \\
X2.10 & 0.777 & Valid & .965 & Reliabel \\
X2.11 & 0.854 & Valid & .963 & Reliabel \\
X2.12 & 0.871 & Valid & .963 & Reliabel \\
X2.15 & 0.871 & Valid & .963 & Reliabel \\
Y1 & 0.776 & Valid & .944 & Reliabel \\
Y2 & 0.786 & Valid & .943 & Reliabel \\
Y3 & 0.919 & Valid & .934 & Reliabel \\
Y4 & 0.861 & Valid & .938 & Reliabel \\
Y5 & 0.738 & Valid & .946 & Reliabel \\
Y6 & 0.782 & Valid & .944 & Reliabel \\
Y7 & 0.912 & Valid & .934 & Reliabel \\
\hline
\end{tabular}

Sumber : data diolah, 2020 
Tabel 2 Karakteristik Responden

\begin{tabular}{lll}
\hline Karakteristik & Jumlah Responden (orang) & Persentase (\%) \\
\hline Jenis Kelamin & & \\
Laki-Laki & 45 & 49 \\
Perempuan & 47 & 51 \\
Jumlah & 92 & 100 \\
Usia Responden & & \\
21 - 30 tahun & 29 & 32 \\
31 - 40 tahun & 40 & 43 \\
41 - 50 tahun & 23 & 25 \\
Jumlah & 92 & 100 \\
Pendidikan Responden & & \\
SMA/Sederajat & 18 & 19 \\
D1, D2, D3 & 28 & 31 \\
Sarjana & 46 & 50 \\
Jumlah & 92 & 100 \\
Pekerjaan Responden & & \\
Polri/ABRI & 10 & 11 \\
Pegawai Negeri Sipil(PNS) & 25 & 27 \\
Pegawai Swasta & 20 & 22 \\
Wiraswasta & 30 & 33 \\
Pelajar/Mahasiswa & 7 & 7 \\
Jumlah & 92 & $100 \%$ \\
Pendapatan Responden & & \\
<Rp. 3.000.000 & 10 & 11 \\
Rp. 3.000.000 - Rp. 5.000.000 & 25 & 27 \\
Rp. 6.000.000 - Rp. 10.000.000 & 38 & 41 \\
>Rp. 10.000.000 & 19 & 21 \\
Jumlah & 92 & $100 \%$ \\
\hline Sur & &
\end{tabular}

Sumber : data diolah, 2020

\section{Deskripsi Variabel Penelitian}

Berdasarkan data pada Tabel 3 secara keseluruhan rata-rata skor variabel Service Excelentadalah 50,08 tergolong kategori setuju, dan rata-rata skornya adalah 3,85 yang mana termasuk kategori setuju. Hal tersebut dapat dijelaskan bahwa nasabah merasa pelayanan dari karyawan ke nasabah di Bank Mandiri Cabang Kesiman sangat mengerti dan memahami apa yang di butuhkan atau diinginkan oleh nasabah dalam hal kredit. 
Tabel 3 Deskripsi Variabel Service Excellent

\begin{tabular}{|c|c|c|c|c|c|c|c|}
\hline \multirow[b]{2}{*}{ Item Pernyataan } & \multicolumn{5}{|c|}{ Jawaban } & \multirow{2}{*}{$\begin{array}{l}\text { Rata- } \\
\text { rata } \\
\text { Skor } \\
\end{array}$} & \multirow{2}{*}{$\begin{array}{l}\text { Kategori } \\
\text { Penilaian }\end{array}$} \\
\hline & 1 & 2 & 3 & 4 & 5 & & \\
\hline $\begin{array}{l}\text { Karyawan PT. Bank Mandiri Cabang } \\
\text { Kesiman ramah }\end{array}$ & 1 & 3 & 19 & 51 & 18 & 3.89 & Baiik \\
\hline $\begin{array}{l}\text { Karyawan PT. Bank Mandiri Cabang } \\
\text { Kesiman dapat dipercaya }\end{array}$ & 1 & 6 & 27 & 34 & 24 & 3.8 & Baik \\
\hline $\begin{array}{l}\text { Karyawan PT. Bank Mandiri Cabang } \\
\text { Kesiman mengerti kebutuhan saya }\end{array}$ & 0 & 2 & 24 & 46 & 20 & 3.91 & Baik \\
\hline $\begin{array}{l}\text { Karyawan PT. Bank Mandiri Cabang } \\
\text { Kesiman mengerti setiap masalah } \\
\text { yang saya tanyakan }\end{array}$ & 0 & 2 & 23 & 46 & 21 & 3.93 & Baik \\
\hline $\begin{array}{l}\text { Karyawan PT. Bank Mandiri Cabang } \\
\text { Kesiman memberikan bantuan sampai } \\
\text { masalah saya tuntas }\end{array}$ & 0 & 5 & 21 & 47 & 19 & 3.86 & Baik \\
\hline $\begin{array}{l}\text { Karyawan PT. Bank Mandiri Cabang } \\
\text { Kesiman melayani dengan cepat }\end{array}$ & 1 & 5 & 22 & 45 & 19 & 3.82 & Baik \\
\hline $\begin{array}{l}\text { Karyawan PT. Bank Mandiri Cabang } \\
\text { Kesiman melayani dengan tepat } \\
\text { Karyawan PT. Bank Mandiri Cabang }\end{array}$ & 0 & 3 & 21 & 53 & 15 & 3.86 & Baik \\
\hline $\begin{array}{l}\text { Kesiman komunikatif dalam } \\
\text { memberikan pelayanan }\end{array}$ & 1 & 4 & 31 & 35 & 22 & 3.79 & Baik \\
\hline $\begin{array}{l}\text { Komunikasi yang baik membuat saya } \\
\text { merasa nyaman ketika dilayani oleh } \\
\text { karyawan PT. Bank Mandiri Cabang } \\
\text { Kesiman } \\
\text { Karyawan PT. Bank Mandiri Cabang }\end{array}$ & 0 & 1 & 28 & 45 & 18 & 3.86 & Baik \\
\hline $\begin{array}{l}\text { Kesiman memiliki pengetahuan cukup } \\
\text { mengenai produk kredit } \\
\text { Karyawan PT. Bank Mandiri Cabang }\end{array}$ & 0 & 2 & 25 & 45 & 20 & 3.9 & Baik \\
\hline $\begin{array}{l}\text { Kesiman kompeten menjelaskan } \\
\text { produk kredit }\end{array}$ & 0 & 5 & 21 & 51 & 15 & 3.82 & Baik \\
\hline $\begin{array}{l}\text { Karyawan PT. Bank Mandiri Cabang } \\
\text { Kesiman memahami masalah yang } \\
\text { saya alami dalam proses kredit }\end{array}$ & 0 & 7 & 24 & 45 & 16 & 3.76 & Baik \\
\hline $\begin{array}{l}\text { Saya sangat terbantu oleh solusi yang } \\
\text { diberikan karyawan PT. Bank } \\
\text { Mandiri Cabang Kesiman dalam } \\
\text { proses kredit }\end{array}$ & 0 & 5 & 21 & 51 & 15 & 3.82 & Baik \\
\hline Rata-rata variabel & & & & & & 3.85 & Baik \\
\hline
\end{tabular}

Sumber : data diolah, 2020

Berdasarkan Tabel 4 skor variabel Nilai Nasabah adalah 58,33 yang mana termasuk kategori setuju, dan rata-rata skornya adalah 3,88 yang mana termasuk kategori setuju. Hal tersebut dapat dijelaskan nasabah dalam melakukan pengajuan kreditnya nasabah tidak dipersulit dalam persyaratan kreditnya 
Tabel 4 Deskripsi Variabel Nilai Nasabah

\begin{tabular}{|c|c|c|c|c|c|c|c|}
\hline \multirow[b]{2}{*}{ Item pernyataan } & \multicolumn{5}{|c|}{ Jawaban } & \multirow{2}{*}{$\begin{array}{l}\text { Rata- } \\
\text { rata } \\
\text { Skor }\end{array}$} & \multirow{2}{*}{$\begin{array}{l}\text { Kategori } \\
\text { Penilaian }\end{array}$} \\
\hline & 1 & 2 & 3 & 4 & 5 & & \\
\hline $\begin{array}{llll}\text { Kredit } & \text { pada } & \text { PT. } & \text { Bank }\end{array}$ & & & & & & & \\
\hline $\begin{array}{l}\text { MandiriCabangKesiman } \quad \text { membantu } \\
\text { hambatan finansial saya }\end{array}$ & 0 & 0 & 26 & 43 & 23 & 3.96 & Baik \\
\hline $\begin{array}{l}\text { Program kredit dari PT. Bank Mandiri } \\
\text { Cabang Kesiman menunjang segala } \\
\text { aktifitas keuangan saya }\end{array}$ & 0 & 0 & 22 & 29 & 41 & 4.2 & Baik \\
\hline $\begin{array}{l}\text { Setelah mengajukan kredit pada PT. Bank } \\
\text { Mandiri Cabang Kesiman, saya mengetahui } \\
\text { tahapan dalam pengajuan kredit }\end{array}$ & 0 & 2 & 25 & 35 & 30 & 4.01 & Baik \\
\hline $\begin{array}{l}\text { Setelah mengajukan kredit pada PT. Bank } \\
\text { Mandiri Cabang Kesiman, saya mengetahui } \\
\text { syarat dalam pengajuan kredit }\end{array}$ & 0 & 4 & 25 & 37 & 26 & 3.92 & Baik \\
\hline $\begin{array}{l}\text { Setelah mengajukan kredit pada PT. Bank } \\
\text { Mandiri Cabang Kesiman, saya mengetahui } \\
\text { jenis-jenis kredit }\end{array}$ & 0 & 6 & 18 & 46 & 22 & 3.91 & Baik \\
\hline $\begin{array}{l}\text { Karyawan PT. Bank Mandiri Cabang } \\
\text { Kesiman menjadi mitra baik saya }\end{array}$ & 2 & 8 & 31 & 35 & 16 & 3.59 & Baik \\
\hline $\begin{array}{l}\text { Saya merasa nyaman ketika berkomunikasi } \\
\text { dengan karyawan pada PT. Bank Mandiri } \\
\text { Cabang Kesiman }\end{array}$ & 0 & 2 & 27 & 46 & 17 & 3.84 & Baik \\
\hline $\begin{array}{l}\text { Saya tidak merasa terbebani secara } \\
\text { finansial ketika mengajukan kredit pada } \\
\text { PT. Bank Mandiri CabangKesiman }\end{array}$ & 0 & 2 & 24 & 49 & 17 & 3.88 & Baik \\
\hline $\begin{array}{l}\text { Saya mendapatkan manfaat lebih besar } \\
\text { dibandingkan biaya yang keluar selama } \\
\text { pengajuan kredit }\end{array}$ & 0 & 4 & 24 & 43 & 21 & 3.88 & Baik \\
\hline $\begin{array}{l}\text { Pelayaran kredit pada PT. Bank Mandiri } \\
\text { Cabang Kesiman cepat }\end{array}$ & 0 & 6 & 16 & 49 & 21 & 3.92 & Baik \\
\hline $\begin{array}{l}\text { Pelayanan prima pada PT. Bank Mandiri } \\
\text { Cabang Kesiman menyebabkan saya tak } \\
\text { perlu membuat energi banyak ketika } \\
\text { mengajukan kredit }\end{array}$ & 0 & 4 & 24 & 51 & 13 & 3.79 & Baik \\
\hline $\begin{array}{l}\text { Saya merasa nyaman mengajukan kredit } \\
\text { pada PT. Bank Mandiri Cabang Kesiman }\end{array}$ & 0 & 2 & 28 & 45 & 17 & 3.83 & Baik \\
\hline $\begin{array}{l}\text { Pengajuan kredit pada PT. Bank Mandiri } \\
\text { Cabang tanpa tekanan }\end{array}$ & 0 & 2 & 27 & 46 & 17 & 3.84 & Baik \\
\hline & & & & & & 3.88 & Baik \\
\hline
\end{tabular}

Sumber : data diolah, 2020

Dari Tabel 5, rata-rata skor menunjukan secara keseluruhan rata-rata skor variabel kepuasan nasabah adalah 35,04dan rata-rata skornya adalah 3,89 yang mana termasuk kategori setuju. Hal tersebut dapat dijelaskan bahwa nasabah di Bank Mandiri cabang kesiman dalam proses kreditnya dilakukan sesuai dengan prosedur bank dan proses kredit tidak sampai memakan waktu yang lama. 
Tabel 5 Deskripsi Variabel Kepuasan Nasabah

\begin{tabular}{|c|c|c|c|c|c|c|c|}
\hline \multirow{2}{*}{ Indikator } & \multicolumn{5}{|c|}{ Jawaban } & \multirow{2}{*}{$\begin{array}{l}\text { Rata-rata } \\
\text { Skor }\end{array}$} & \multirow{2}{*}{$\begin{array}{l}\text { Kategori } \\
\text { Penilaian }\end{array}$} \\
\hline & 1 & 2 & 3 & 4 & 5 & & \\
\hline $\begin{array}{l}\text { Saya merasa puas terhadap pelayanan } \\
\text { karyawan PT. Bank Mandiri Cabang } \\
\text { Kesiman dalam pencairan kredit. }\end{array}$ & 2 & 2 & 28 & 41 & 19 & 3.79 & Baik \\
\hline $\begin{array}{l}\text { Saya merasa puas terhadap pelayanan } \\
\text { karyawan PT. Bank Mandiri Cabang } \\
\text { Kesiman dalam pembayaran kredit. }\end{array}$ & 0 & 1 & 24 & 39 & 28 & 4.02 & Baik \\
\hline $\begin{array}{l}\text { Saya merasa puas terhadap produk kredit } \\
\text { pada PT. Bank Mandiri Cabang Kesiman } \\
\text { Saya bersedia menggunakan produk }\end{array}$ & 0 & 3 & 23 & 44 & 22 & 3.92 & Baik \\
\hline $\begin{array}{l}\text { kredit pada PT. Bank Mandiri Cabang } \\
\text { Kesiman }\end{array}$ & 0 & 3 & 25 & 41 & 23 & 3.91 & Baik \\
\hline $\begin{array}{l}\text { Saya bersedia menyarankan produk } \\
\text { kredit pada PT. Bank Mandiri Cabang } \\
\text { Kesiman }\end{array}$ & 0 & 5 & 19 & 48 & 20 & 3.9 & Baik \\
\hline $\begin{array}{l}\text { Saya bersedia menyarankan produk } \\
\text { kredit pada PT. Bank Mandiri Cabang } \\
\text { Kesiman kepada teman dekat saya } \\
\text { Proses Pencairan kredit pada PT. Bank }\end{array}$ & 0 & 6 & 28 & 40 & 18 & 3.76 & Baik \\
\hline $\begin{array}{l}\text { Mandiri Cabang Kesiman sesuai dengan } \\
\text { harapan saya }\end{array}$ & 0 & 3 & 23 & 45 & 21 & 3.91 & Baik \\
\hline $\begin{array}{l}\text { Pelayanan kredit pada PT Bank Mandiri } \\
\text { Cabang Kesiman sesuai dengan harapan } \\
\text { saya }\end{array}$ & 0 & 3 & 25 & 42 & 22 & 3.9 & Baik \\
\hline $\begin{array}{l}\text { Permohonan pengajuan kredit pada PT. } \\
\text { Bank Mandiri Cabang Kesiman sesuai } \\
\text { dengan harapan saya }\end{array}$ & 0 & 3 & 23 & 45 & 21 & 3.91 & Baik \\
\hline & & & & & & 35.04 & Baik \\
\hline
\end{tabular}

Sumber : data diolah, 2020

\section{Uji Asumsi Klasik}

Pada gambar 2 terlihat titik-titik menyebar di sekitar garis diagonal, serta penyebarannya mengikuti arah garis diagonal. Dengan demikian dapat dikatakan model regresi sebagaimana dibahas di depan telah memenuhi asumsi Normalitas, dan layak dipakai untuk memprediksi variabel terikatnya. 


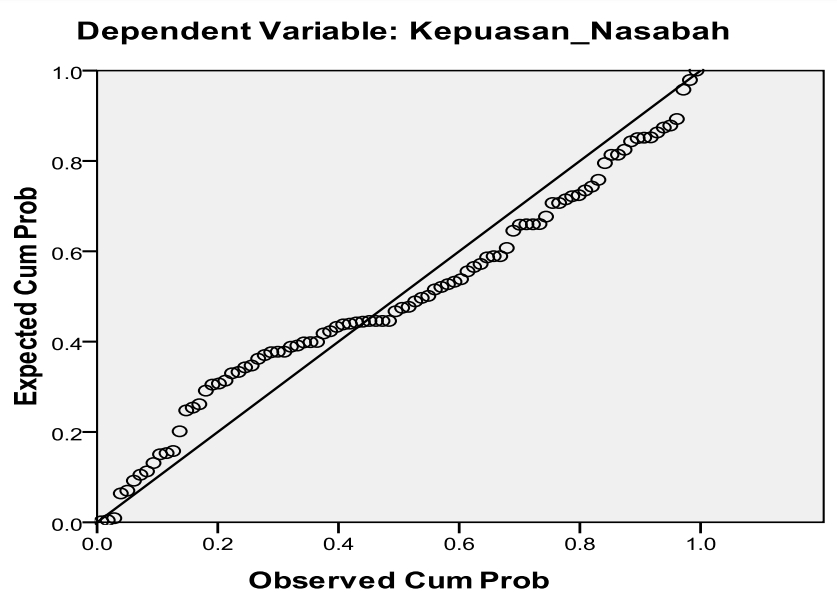

Gambar 2 Hasil Uji Normalitas

Hasil uji multikolinearitas pada Tabel 6 menunjukkan bahwa nilai tolerance variabel bebas berada di atas 0,1 dan nilai VIF berada di bawah 10. Jadi dapat disimpulkan bahwa model tidak terdapat gejala multikolinearitas.

\section{Tabel 6 Hasil Uji Multikolinearitas}

\begin{tabular}{lll}
\hline Variabel & Nilai Tolerance & Nilai VIF \\
\hline Service Excelent & 0,543 & 1,841 \\
Nilai Nasabah & 0,543 & 1,841 \\
\hline
\end{tabular}

Sumber : data diolah, 2020

Memperhatikan Scatterplot pada Gambar 3, terlihat titik-titik menyebar secara acak, di atas maupun dibawah angka 0 pada sumbu Y serta di kiri maupun di kanan sumbu X. Hal ini berarti tidak terjadi Heteroskedastisitas pada model regresi, sehingga model regresi yang diperoleh layak dipakai untuk memprediksi besarnya variabel terikat berdasar masukan variabel bebas. 


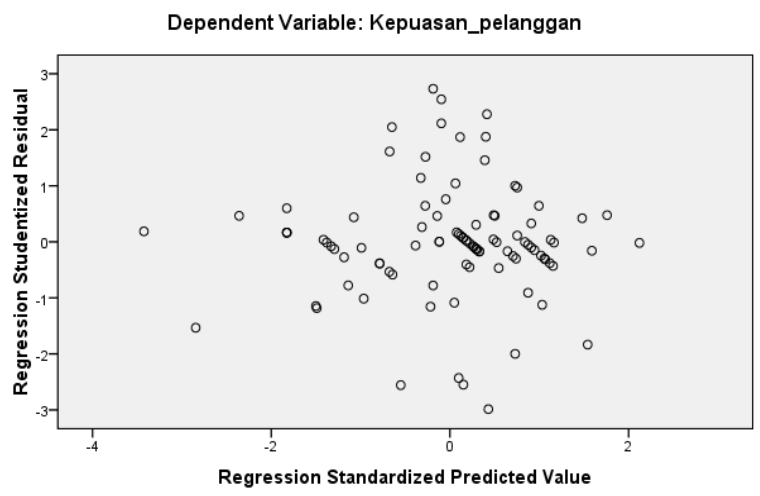

\section{Gambar 3 Hasil Uji Heteroskedastisitas}

Sumber : data diolah, 2020

\section{Analisis Regresi Linear Berganda}

Analisis ini digunakan untuk mengetahui derajat atau kekuatan hubungan antara tiga variabel atau lebih serta mengetahui kontribusi yang diberikan secara simultan Service Excelent, Nilai Nasabah, dan kepuasan nasabah dengan bantuan program SPSS version 17.0 for windows.

\section{Tabel 7 Hasil Analisis Regresi Linear Berganda}

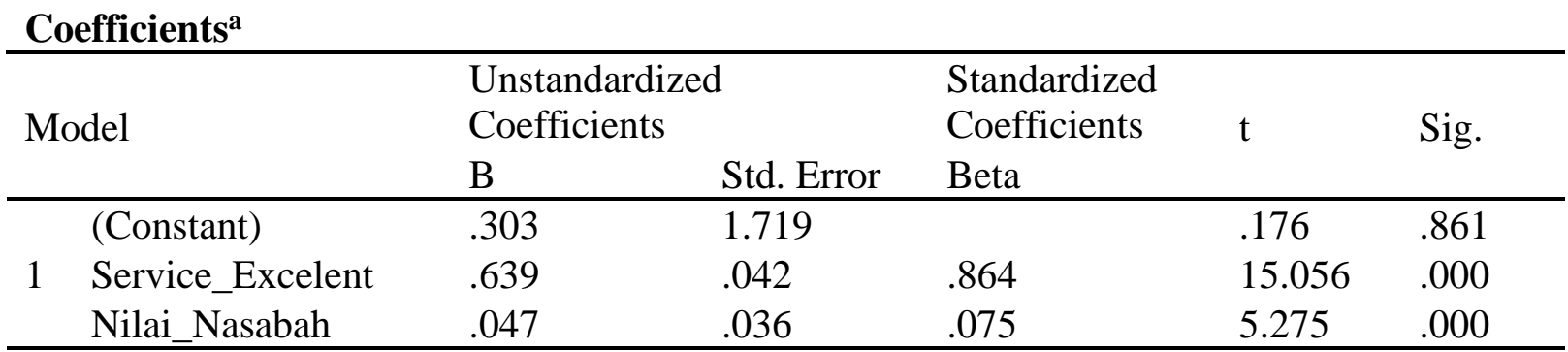

a. Dependent Variable: Kepuasan_Nasabah

Sumber : data diolah, 2020

Berdasarkan Tabel 7, dapat dibuat persamaan regresi linier berganda pola pengaruh variabel bebas

Service Excelent $\left(\mathrm{X}_{1}\right)$ dan Nilai Nasabah $\left(\mathrm{X}_{2}\right)$ terhadap variabel terikat kepuasan nasabah(Y), sebagai berikut:

$Y=a+b_{1} X_{1}+b_{2} X_{2}$ sehingga menjadi $Y=0,303+0,639 X_{1}+0,047 X_{2}$

Dari persamaan tersebut maka dapat dikemukakan interprestasi apabilaService Excelent $\left(\mathrm{X}_{1}\right)$ dan Nilai Nasabah $\left(\mathrm{X}_{2}\right)$ masing-masing satu satuan, maka besarnya kepuasan nasabah $(\mathrm{Y})$ dari 0,303satuan menjadi sebesar 0,989satuan atau kepuasan nasabah (Y) meningkat sebesar $=0,303$ $(0,989)=0,686$ satuan.Bedasarkan penjelasan di atas, secara umum dapat dinyatakan bahwa, 
Service Excelent $\left(\mathrm{X}_{1}\right)$ dan Nilai Nasabah $\left(\mathrm{X}_{2}\right)$ secara bersama memiliki pola pengaruh positif terhadapkepuasan nasabah (Y).Inimenunjukkan bahwa apabila,Service Excelent $\left(\mathrm{X}_{1}\right)$ dan Nilai Nasabah $\left(\mathrm{X}_{2}\right)$ secara besama-sama ditingkatkan,maka kepuasan nasabah (Y) akan meningkat. Sebaliknya, apabila Service Excelent $\left(\mathrm{X}_{1}\right)$ dan Nilai Nasabah $\left(\mathrm{X}_{2}\right)$ secara besama-sama menurun, maka akan terjadi penurunan kepuasan nasabah (Y).

\section{Uji Signifikansi Parsial (Uji T)}

Sesuai dengan hipotesis 1, maka pada analisis ini dibahas pengaruh Service Excelent $\left(\mathrm{X}_{1}\right)$ terhadap kepuasan nasabah (Y), sementara Nilai Nasabah $\left(\mathrm{X}_{2}\right)$ konstan (atau dikontrol), untuk menguji signifikan tidaknya koefisien regresi, maka dilakukan pengujian menggunakan uji-t $\left(\mathrm{t}_{\text {-test}}\right)$.

\section{Tabel 8 Hasil Uji T}

\section{Coefficients $^{\mathbf{a}}$}

\begin{tabular}{|c|c|c|c|c|c|c|}
\hline \multirow{3}{*}{\multicolumn{2}{|c|}{ Model }} & \multirow{2}{*}{\multicolumn{2}{|c|}{$\begin{array}{l}\text { Unstandardized } \\
\text { Coefficients }\end{array}$}} & \multirow{3}{*}{$\begin{array}{l}\text { Standardized } \\
\text { Coefficients } \\
\text { Beta }\end{array}$} & \multirow{3}{*}{$\mathrm{t}$} & \multirow{3}{*}{ Sig. } \\
\hline & & & & & & \\
\hline & & $\mathrm{B}$ & Std. Error & & & \\
\hline \multirow{3}{*}{1} & (Constant) & .303 & 1.719 & & .176 & .861 \\
\hline & Service_Excelent & .639 & .042 & .864 & 15.056 & .000 \\
\hline & Nilai_Nasabah & .047 & .036 & .075 & 5.275 & .000 \\
\hline
\end{tabular}

a. Dependent Variable: Kepuasan_Nasabah

Sumber : data diolah, 2020

\section{Pengaruh Service Excellent Terhadap Kepuasan Nasabah}

Sesuai dengan hasil peneliitian di mana nilai $t_{\text {hitung }}=15,056$ lebih besar dibandingkan dengan nilai $\mathrm{t}_{\text {tabel }}=2,000$ serta nilai signifikan sebesar 0,000 lebih kecil dari 0,005, dan $t_{\text {hitung }}$ berada pada daerah penolakan $\mathrm{H}_{0}$. Ini berarti bahwa secara statistik untuk uji satu sisi padataraf kepercayaan $(\alpha)=5 \%$, secara parsial Service Excelent $\left(\mathrm{X}_{1}\right)$ berpengaruh positif dansignifikan terhadap kepuasan nasabah (Y) serta didukung juga pada faktor Service Excelent mempengaruhi kepuasan nasabah pada PT. Bank Mandiri Cabang Kesiman, oleh karena itu hipotesis yang diajukan terbukti dan teruji kebenarannya.

Pentingnya Service Excellent dimana yang dimaksud pelayanan telah diungkapkan sejumlah peneliti. Berbagai riset menunjukkan pengaruh yang signifikan Service Excellent terhadap kepuasan. Penelitian yang dilakukan Hasibuan dalam Bakri (2015 :14) bentuk pelayanan prima yang baik adalah pelayanan yang dilakukan dengan ramah, cepat, tepat, dan nyaman sehingga memnuhi kepuasan nasabahnya. Sedangkan menurut Barata dalam Bakri (2015:15) pelayanan 
yang prima dengan menyelaraskan faktor-faktor antara lain, kemampuan (ability), sikap (attitude), penampilan (appearance), perhatian (attention), tindakan (action), dan tanggung jawab (responsibility).

\section{Pengaruh Nilai NasabahTerhadap Kepuasan Nasabah}

Sesuai dengan hasil peneliitian di mana nilai $t_{\text {hitung }}=5,275$ dibandingkan dengan nilai $t_{\text {tabel }}=2,000$, serta nilai signifikan sebesar 0,000 lebih kecil dari 0,005, dan thitung berada pada daerah penolakan $\mathrm{H}_{0}$. Ini berarti bahwa secara statistik untuk uji satu sisi pada taraf kepercayaan $(\alpha)=5 \%$, secara parsial Nilai Nasabah $\left(\mathrm{X}_{2}\right)$ berpengaruh positif dansignifikan terhadap kepuasan nasabah $(\mathrm{Y})$ serta didukung juga pada faktor Nilai Nasabah mempengaruhi kepuasan nasabah pada PT. Bank Mandiri Cabang Kesiman, oleh karena itu hipotesis yang diajukan terbukti dan teruji kebenarannya.

Berbagai studi menunjukkan, nilai nasabah merupakan faktor kunci mempengaruhi kepuasan nasabah. Menurut Slywotzky dalam Astono (2017) menyatakan bahwa nilai nasabah (customer value) adalah perpektif nasabah dalam mempertimbangkan apa yang mereka inginkan dan yakini dari pembelian dan penggunaan suatu produk, Zeithaml dalam Astono (2017) yang menyatakan bahwa nilai nasabah (customer value) adalah penilaian keseluruhan nasabah terhadap utilitas sebuah produk atau layanan berdasarkan persepsinya terhadap apa yang diterima dan uang diberikan. Berdasarkan pendapat para ahli, nilai nasabah adalah persepsi dari sebuah utilitas produk dalam pempertimbangkan apa yang mereka inginkan.Menurut Holbrook dalam Suhastomo (2015) mengidentifikasi delapan tipe nilai pelanggan utama dalam pengalaman konsumsi yaitu, Eficiency Value (Rasio Output atau Input atau convinence value),Excellence Value, Political Value (kesuksesan), Esteem Value (Reputasi), Play Value (Kesenangan), Estehtic Value (Keandalan), Morality Value (Kebajikan), Spiritual Value (Keyakinan).

\section{Uji Signifikansi Simultan (Uji F)}

F-test digunakan untuk membuktikan apakah pengaruh Service Excelentdan Nilai Nasabahsecara serempak berpengaruh terhadap kepuasan nasabah pada PT. Bank Mandiri Cabang Kesiman Di Denpasar.

\section{Tabel 9 Hasil Uji F}

\begin{tabular}{|c|c|c|c|c|c|c|}
\hline \multicolumn{7}{|c|}{ ANOVA $^{b}$} \\
\hline & del & Sum of Squares & $\mathrm{df}$ & Mean Square & $\mathrm{F}$ & Sig. \\
\hline \multirow{3}{*}{1} & Regression & 2812.98 & 2 & 1406.49 & 234.923 & $.000^{\mathrm{a}}$ \\
\hline & Residual & 532.846 & 89 & 5.987 & & \\
\hline & Total & 3345.826 & 91 & & & \\
\hline
\end{tabular}

Sumber : data diolah, 2020 
Sesuai dengan hasil penelitian dimana nilai nilai F-tabel sebesar 2,76dan nilai F-hitung sebesar 234,923, sehingga jika dibandingkan nilai F-hitung lebih besar dari F-tabel dan F-hitung berada pada daerah penolakan Ho maka Ha diterima. Ini berarti bahwaService Excelent dan Nilai Nasabahberpengaruh positif dan signifikan terhadapkepuasan nasabahpada PT. Bank Mandiri Cabang Kesiman Di Denpasar. Oleh karena itu hipotesis yang diajukan terbukti dan teruji kebenarannya.

Kotler Dan Keller (2012:150) Kepeuasan adalah perasaan puas atau kecewa seseorang yang dihasilkan dari perbandingan performa produk atau hasil dengan ekspektasi. Konsumen yang puas akan mengkonsumsi produk tersebut secara terus menerus, mendorong nasabah untuk loyal terhadap produk atau jasa dan senang hati mempromosikan produk dan jasa tersebut kepada orang lain dari mulut ke mulut. Ada faktor yang berpengaruh terhadap terhadap kepuasan nasabah, diantaranya yaitu service excellent dan nilai nasabah, hal tersebut sejalan dengan hasil penelitian yang dilakukan oleh Khaeirunisa (2013) yang menyatakan bahwa service excellent berpengaruh signifikan terhadap kepuasan nasabah begitu juga dengan peneliti yang dilakukan oleh Ikasari, dkk (2013) menyatakan bahwa nilai nasabah mempunyai pengaruh positif dan signifikan terhadap kepuasan pelanggan.

\section{SIMPULAN}

Sesuai dengan hasil penelitian dan pembahasan yang telah diuraikan pada bab sebelumnya, maka dapat ditarik kesimpulan sebai berikut:

1. Berdasarkan keseluruhan hasil pengujian diatas, maka diperoleh persamaan regresi berganda sebagai berikut: $\mathrm{Y}=0,303+0,639 \mathrm{X}_{1}+0,047 \mathrm{X}_{2}$ yang dapat diartikan secara simultan PengaruhService Excelent dan Nilai Nasabah berpengaruh terhadap kepuasan nasabah pada PT Bank Mandiri Cabang Kesiman Di Denpasar.

2. Berdasarkan Hasil penelitian dimana nilai t-hitung masing-masing variabel di antarannya Service Excelent (X1) 15,056 dan nilai nasabah t-tabel 1,980 jika dibandingkan maka nilai t-hitung lebih besar dari nilai t-tabel dan t-hitung berada pada daerah penolakan Ho, Nilai Nasabah (X2) 5,275 dan nilai t-tabel 2,000. sehingga jika dibandingkan maka nilai t-hitung lebih besar dari nilai t-tabel dan t-hitung berada pada daerah penolakan Ho. Oleh karena itu Ho ditolak dan Ha diterima ini berarti bahwa service excellent dan nilai nasabahberpengaruh positif dan signifikan terhadap kepuasan nasabah. 
3 Berdasarkan Hasil penelitian dimana nilai F hitung $(234,923)>$ F-tabel $(2,76)$ dengan tingkat signifikan 0,000. sehingga jika dibandingkan nilai F-hitung lebih besar dari F-tabel dan Fhitung berada pada daerah penolakan Ho maka Ha diterima. Ini berarti bahwaservice execelent dan Nilai Nasabah berpengaruh positif dan signifikan terhadap kepuasan nasabah pada PT. Bank Mandiri cabang Kesiman.

\section{SARAN}

Berdasarkan hasil penelitian pada PT Bank Mandiri Cabang Kesiman diharapkan dapat memberikan sumbangan pemikiran bagi peningkatan kepuasan nasabah pada PT Bank Mandiri Cabang Kesiman di Denpasar :

1. Service ExcelentBerkaitan dengan Service Excelent, PT. Bank Mandiri Cabang Kesiman Di Denpasar hendaknya memberikan perhatian terhadap indikator tersedianya karyawan yang baik, bertanggung jawab kepada setiap pelanggan sejak awal hingga akhir, Mampu melayani secara cepat dan tepat, mampu berkomunikasi, memiliki pengetahuan dan kemampuan yang baik, berusaha memahami kebutuhan pelanggan. Karyawan PT Bank Mandiri Cabang Kesiman harus memahami masalah nasabah yang dialami dalam proses kredit dan selalu menjaga hubungan dengan konsumen.

2 Berkaitan dengan Nilai Nasabah, PT Bank Mandiri Cabang Kesiman Di Denpasar hendaknya memberikan perhatian terhadap indikator Nilai produk, Nilai layanan ,Nilai personel, Nilai moneter, Biaya waktu, Biaya energy, Biaya psikis. Karyawan PT Bank Mandiri Cabang Kesiman menjadi mitra baik saya.

3 Penelitian selanjutnya disarankan melibatkan responden yang lebih beragam, dan juga menggunakan metode pengambilan sampel yang lebih representative. Selain itu perlu dikaji hubungan langsung variabel independen terhadap kepuasan konsumen sehingga dapat diketahui hubungan antar variabel yang lebih komprehensif. Selanjutnya dapat digunakan sebagai bahan pertimbangan oleh pihak pengelola warung untuk mengevaluasi segmen dan pangsa pasarnya dalam meningkatkan kinerja dan daya saing perbankkan.

\section{DAFTAR PUSTAKA}

Sekaran, Uma.(2007) Metode penelitian untuk Bisnis) (Edisi 4 Jilid 1). Jakarta: Salemba Empat. Hasibuan Malayu, Manajemen Sumber Daya Manusia.Jakarta:PT Toko Gunung Agung.2001

Kotler, Philip dan Garry Amstrong.2001. Prinsip-prinsip Pemasaran. Jakarta: Erlangga.

Kotler, Philip.2003. ManajemenPemasaran: Analisis, Perencanaan, Implementasi dan Pengendalian. Jakarta: Indeks. 
Kotler, Philip dan Lane Keller.2006. Manajemen Pemasaran. Edisi ke 12. Jakarta: Indeks. Kotler, Philip. 2008. Prinsip-Prinsip Pemasaran. Buku Kedua. Edisi ke 12. Jakarta; PT. Indeks.

Kotller dan Keller.2012.Manajemen Pemasaran.Edisi Kesebelas.Penerbit Indeks. Jakarta.

Sekaran, Uma. (2008) MeTode penelitian untuk Bisnis (Edisi 4 Jilid 2). Jakarta: Salemba Empat.Service).

Slywotzky,A.J.1996. Value Migration.Boston:Harvand Business School Press.

Sugiyono, Prof. Dr.(2009) Statistika Untuk Penelitian. Bandung: Alfabeta,cv.

Sumarwan dkk. (2011). Riset Pemasaran dan Konsumen. Bogor: IPB Press.

Sunyoto, Danang. 2014. Konsep Dasar Riset Pemasaran dan Perilaku Konsumen.

Sunyoto, Danang.(2009). Analisis Regresi dan Uji Hipotesis, Yogyakarta: Media Pressindo.

Sunyoto, Danang. (2012). Konsep Dasar Riset Pemasaran dan Perilaku Nasabah, Yogyakarta:

CAPS.

Tjiptono, Fandy dab Gregorius Chandra. 2005.Pemasaran Strategik. Yogyakarya: Andi

Tjiptono,Fandy.2006. Pemasaran Jasa. Malang: Banyu Media Tjiptono, Fandy. 2007.

Pemasaran Jasa Edisi Pertama: Cetakan Ketiga. Penerbit Bayumedia Publising. Malang. Tjiptono, Fandy. 2008. Service Management: Mewujudkan Layanan Prima. Yogyakarta: Andi Offset Tjiptono, Fandy, Gregorius Chandra dan Dadi Adriana (2008). Pemasaran Strategik. Yogyakarta: ANDI.

Tjiptono, Fandy.2014. Pemasaran jasa,Bayumedia Publishing,Malang. 